\title{
Rh ANTIBODIES AND THE PROZONE PHENOMENON
}

\author{
BY \\ P. H. RENTON AND JEANNE A. HANCOCK \\ From the National Blood Transfusion Service, Roby Street, Manchester, 1
}

(RECEIVED FOR PUBLICATION APRIL 10, 1957)

In 1942 Taylor, Race, Prior, and Ikin reported an anti-Rh serum which failed to agglutinate $R h-$ positive cells in saline suspension except when diluted. They thought that this prozone was due to antigen and antibody not being present in optimal proportions, and that the mechanism was similar to that of the zones that occur in precipitation reactions.

Wiener (1944) described incomplete $R$ h antibodies and their blocking effects, and considered that this type of antibody might be responsible for the prozones seen with $\mathrm{Rh}$ antisera.

Subsequently, various other workers observed prozones with anti-human globulin sera, and Hubinont (1951) considered that these were due to lack of optimal proportions between antigen and antibody.

Van Loghem (1950) also investigated the prozones of antiglobulin sera and considered that they might be due either to the presence of blocking antibodies or to overdosage by excessive amounts of agglutinin, i.e., lack of optimal proportions.

Van Loghem, Kresner, Coombs, and Fulton Roberts (1950) considered these two alternative explanations further, and described experiments to show that excess of agglutinin was the cause of the prozone in the particular antiglobulin reagent which they were studying. They suggested that, when agglutinin is present in high concentration, all the available antigen sites on the red cell surface become occupied by molecules of agglutinin, so that none are free to combine with molecules of agglutinin already attached to other cells, and the lattice necessary for agglutination cannot be formed. This was demonstrated by the fact that washed cells from the prozone would agglutinate when mixed with a further supply of cells bearing free antigen receptors. Cells from the prozone also agglutinated on the addition of suitable concentrations of human $\gamma$ globulin. The conclusion drawn from these experiments, that the prozone, in this particular case at any rate, was caused by excessive amounts of agglutinin and not by incomplete antibody, appears at first sight to be irrefutable. Nevertheless, certain considerations led us to suppose that this conclusion might be incorrect and that the same phenomenon might occur even though the cause of the prozone was incomplete antibody. The first experiment described below shows that that is so, at any rate in the case of $\mathrm{Rh}$ antibodies. The second experiment shows that in some cases even cells from the first negative tube of a titration will agglutinate on the addition of more cells with free receptors.

\section{Experiment 1}

Table I shows the results obtained on titrating an agglutinating and an incomplete serum, and a mixture of these with a $3 \%$ saline suspension of washed $R_{2} r$ (cDE/cde) cells at $37^{\circ} \mathrm{C}$. The serum Ho. is a saline agglutinating anti-D serum and shows no signs of prozone. The serum $P o$. is an incomplete anti-D serum and shows no agglutination at any dilution. The third line of the table shows that a prozone is obtained when a mixture of 1 part serum Ho., 4 parts serum Po., and 3 parts saline is titrated. We consider that this particular prozone is due to the presence of incomplete antibody.

TABLE I

TITRATIONS OF ANTI-D SERA WITH $R_{2}$ r (cDE/cde) CELLS

\begin{tabular}{|c|c|c|c|c|c|c|c|c|c|c|c|}
\hline \multirow{2}{*}{ Serum } & \multicolumn{11}{|c|}{ Reciprocals of Dilutions } \\
\hline & 1 & 2 & 4 & 8 & 16 & 32 & 64 & 128 & 256 & 512 & 1,024 \\
\hline $\begin{array}{l}\text { Ho. } \quad . \\
\text { Po. } \\
\text { Mixture }\end{array}$ & $\frac{\mathbf{v}}{-}$ & $\frac{v}{++}$ & $\frac{\mathbf{v}}{++}$ & $\frac{\mathbf{v}}{++}$ & $\frac{\mathbf{v}}{++}$ & $\frac{v}{+}$ & $\begin{array}{c}+ \pm \\
\pm\end{array}$ & $\begin{array}{c}++ \\
=\end{array}$ & \pm & $\bar{z}$ & $\bar{z}$ \\
\hline
\end{tabular}

* Mixture $=1$ vol. Ho., 4 vol. Po., 3 vol. saline. v,,,,$++++++=$ Degree of agglutination. $-=$ No agglutination. 
In the second part of the experiment a further volume of a $3 \%$ saline suspension of washed $R_{2} r$ (cDE/cde) cells was again incubated with one volume of a mixture of 1 part Ho., 4 parts Po., and 3 parts of saline. After one and a half hours' incubation at $37^{\circ} \mathrm{C}$., the cells were washed three times in saline, restored to a $3 \%$ suspension in saline, and divided into a number of tubes. An equal volume of a $3 \%$ suspension of washed $R_{2} r$ (cDE/cde) cells was added to the first tube, washed $\mathrm{rr}$ (cde/cde) cells to the second tube, a volume of undiluted Ho. to the third tube, and a volume of saline to the fourth tube. Saline from the last washing of the cells of the prozone was simultaneously tested with $\mathbf{R}_{2} \mathbf{R}_{2}$ (cDE/cDE) cells in order to show that there was no free agglutinin in the supernatant. The mixtures were incubated for a further one and a half hours at $37^{\circ} \mathrm{C}$. The results of this experiment are shown in Table II,

TABLE II

REAGENTS ADDED TO WASHED CELLS OF PROZONE ( 1 in 1 dilution of mixture in Table $\mathrm{I}$ )

\begin{tabular}{|c|c|c|c|c|c|}
\hline \multicolumn{5}{|c|}{ Reagents Added to Washed Cells of Prozone } & Result \\
\hline $\begin{array}{l}\mathbf{R}_{2} \mathbf{r}(\mathrm{cDE} \text { cde) cells } \\
\mathrm{rr}(\mathrm{cde} \text { cde) } \\
\text { Serum Ho. } \\
\text { Saline }\end{array}$ & $\begin{array}{l}\cdots \\
\cdots \\
\cdots \\
\cdots\end{array}$ & $\begin{array}{l}\cdots \\
\cdots \\
\cdots \\
\cdots\end{array}$ & $\begin{array}{l}\cdots \\
\cdots \\
\cdots \\
\cdots\end{array}$ & $\begin{array}{l}\cdots \\
\cdots \\
\cdots \\
\cdots\end{array}$ & $\begin{array}{c}+\rightarrow \\
- \\
-\end{array}$ \\
\hline \multicolumn{5}{|c|}{ Last washing tested with $R_{2} R_{2}(\mathrm{cDE}$ cDE) cells } & - \\
\hline
\end{tabular}

and it can be seen that the cells from the prozone agglutinated on the addition of a further quantity of washed $\mathrm{R}_{2} \mathrm{r}$ (cDE/cde) cells, and also on the addition of undiluted Ho., but there was no agglutination in the controls.

\section{Experiment 2}

Table III shows the serum Ho. titrated with a washed suspension of $R_{1}^{u} r$ (CDue/cde) cells. As expected, the titre is much less than with $R_{2} r$

TABLE III

TITRATION OF SALINE AGGLUTINATING ANTI-D SERUM WITH Du CELLS

\begin{tabular}{l|c|c|c|c|c|c|c|c|c}
\hline \multirow{2}{*}{ Serum } & \multicolumn{7}{|c}{ Reciprocals of Dilutions } \\
\hline Ho. & 1 & 2 & 4 & 8 & 16 & 32 & 64 & 128 & 256 \\
\hline
\end{tabular}

(cDE/cde) cells (see Table 1), and there is no agglutination at a dilution of 1 in 64 . In the second part of this experiment a suspension of the $R_{1}{ }^{u} r$ (CDue/cde) cells was again treated with an equal volume of Ho., diluted 1 in 64 . for one and a half hours at $37^{\circ} \mathrm{C}$. and, after washing, was mixed with a volume of washed $R_{2} R_{2}(c D E / c D E)$ cells, washed rr (cde/cde) cells, saline, and undiluted Ho., and again incubated, as in Experiment 1. The last washing was also tested with $\mathrm{R}_{2} \mathbf{R}_{2}$ (cDE/cDE) cells, as before. The results of this experiment are shown in Table IV.
TABLE IV

REAGENTS ADDED TO WASHED CELLS OF FIRST NEGATIVE TUBE IN TITRATION OF TABLE III

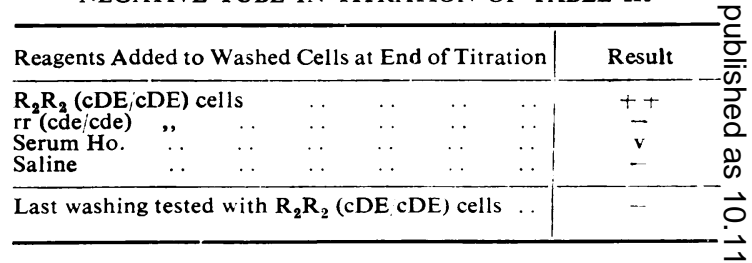

and it can again be seen that the cells agglutinate on $\stackrel{\omega}{\sigma}$ the addition of a further supply of antigen receptors and on the addition of undiluted Ho., but there is:again no agglutination in the control tubes.

It might be argued that in this and the preceding experiment agglutinin was eluted from the cells during $\overrightarrow{0}$ the second period of incubation and that this elutedo agglutinin was responsible for the agglutination of the cells added. In view of this, both experiments werec repeated substituting immediate centrifugation and reading of results for the second period of incubation. The results obtained were the same as before, though the agglutination was a little weaker since low $\overrightarrow{0}$ temperatures and short times are unfavourable to the action of $\mathrm{Rh}$ antibodies.

\section{Discussion}

Two explanations have been suggested toō account for zoning in agglutination systems. Oneूू explanation is that the incomplete antibody is moree avid than the agglutinin, and combines preferen $\overrightarrow{\overrightarrow{0}}$ tially with the antigen, blocking it against the action of the agglutinin. In the high dilutions of a titration, however, only the agglutinin is effec? tive. The second explanation is that the prozone is due to agglutinin excess, i.e., lack of optima? proportions as in the case of precipitation systems According to this explanation the concentration of agglutinin in the prozone is so great that the antio gen receptors of each cell become saturated witho molecules of agglutinin and none are free to com? bine with molecules of agglutinin already attache to other cells. The two hypotheses are not. of course, mutually exclusive.

In their first experiment, van Loghem et al. used an antiglobulin reagent showing a prozone with cells sensitized by incomplete anti-D. Cells frone the prozone were washed and found to agglutinats on the addition of more sensitized cells. This waf considered to show that the prozone in this case was caused by excess agglutinin rather than bto incomplete antibody.

Their second experiment showed that washe cells from the prozone would agglutinate on th addition of suitable concentrations of $\gamma$ globuling The principle in this case does not appear to differ 
from that involved in their first experiment. In each case the cells agglutinate on the addition of more antigen.

Now in our first experiment the prozone was evidently caused by incomplete antibody, since it occurred on the addition of incomplete antibody to an agglutinating serum which showed no prozone itself. Moreover, it can hardly be contended that the prozone in this case was due to excess agglutinin since addition of more agglutinin caused the cells to agglutinate.

The phenomenon of agglutination of cells from the prozone on the addition of more cells with free antigen would be expected, as van Loghem et al. suggest, if the prozone were due to agglutinin excess. However, it appears from our experiments that it also occurs when the prozone is due to incomplete antibody, so that this phenomenon cannot be used as an argument in favour of either mechanism.

Nevertheless, it is not easy to see why this phenomenon should occur when the prozone is due to incomplete antibody. Assuming the correctness of the lattice hypothesis of agglutination due to bivalent agglutinin molecules, agglutination would appear to depend not on how many molecules of agglutinin each cell takes up, but on how many molecules become attached to two cells. We think of agglutination as taking place in two stages. In the first stage the cells are taking up molecules of agglutinin free in the serum, and in the second stage they are taking up molecules already attached to other cells, and are, therefore, agglutinating. The two stages may well be concurrent.

This concept seems to us to be fundamental to an understanding of the subject and is supported by the fact that the length of the prozone is dependent on the spatial relationship of the erythrocytes during the reaction. If the cell suspensions and serum dilutions are mixed, centrifuged immediately, and then incubated at $37^{\circ} \mathrm{C}$. the length of the prozone is diminished; whilst if the tube is repeatedly tapped during incubation and centrifuged afterwards, zoning is increased. It seems that in the first case the close contact of the cells during the reaction promotes the second stage, whilst in the second case the reverse occurs.

The amount of antibody which a cell will take up depends not only on the concentration of antibody present, but also on the amount of antibody which it has already taken up. This is a consequence of the quantitative behaviour of antigen-antibody reactions, and means that a cell whose antigen receptors are free from antibody will take up agglutinin more readily than one whose receptors are already partially occupied by antibody. In the second stage of the reaction agglutinin already attached to one cell is seeking attachment to a second cell, and it can be seen that it will more readily attach itself to a cell with free antigen receptors than to one whose receptors are already partially occupied by other molecules of agglutinin and incomplete antibody. Hence it might happen in a prozone that agglutinin molecules which had already attached themelves to a first cell would be unable to join on to a second in sufficient numbers for agglutination to occur, owing to the presence of other antibody molecules already attached to the second cell. They would, however, readily attach themselves to a cell free from antibody.

Experiment 2 illustrates these ideas further. The $\mathrm{D}^{\mathrm{u}}$ cells in this case have a reduced ability to take up agglutinin as compared with normal $\mathbf{D}$ cells. In the first negative tube of the titration there is no agglutination because the second stage of the reaction has failed. There is, however, enough agglutinin on the cell surface to react with the more potent antigen of $R_{2} R_{2}(\mathrm{cDE} / \mathrm{cDE})$ cells. The importance of this in the present connexion is that this is another case where agglutination occurs on the addition of cells with free antigen receptors. Moreover, it could not possibly be contended here that the absence of agglutination in the first place was due to the presence of excessive amounts of agglutinin.

Such considerations show how the phenomenon of agglutination of cells from the prozone on the addition of cells with free antigen receptors can be accounted for whether the prozone is due to agglutinin excess or to incomplete antibody. They also lead to the supposition that there is no real difference between these two causes of zoning. Both, presumably, are due to "antibody excess," that is, to antibody on the cell surface interfering with the second stage of the reaction.

Now the second stage is favoured by a high concentration of agglutinin at the cell surface, since there is then a large number of agglutinin molecules seeking attachment to a second cell. On the other hand, it is resisted by a high concentration of antibody on the cell surface, since this reduces the ability of the cell to take up agglutinin already attached to another cell. It does not matter in this connexion whether the cells have taken up agglutinin alone or both incomplete antibody and agglutinin in the first stage of the reaction; either will have the effect of reducing the ability of the cell to take up agglutinin in the 
second stage. In short, agglutination is promoted by high concentrations of agglutinin at the cell surface but is resisted by high concentrations of antibody (agglutinin or incomplete).

The effect of increasing the concentration of agglutinin is thus twofold. On the one hand it tends to increase agglutination, and on the other hand, by occupying the red cell surface, it interferes with the second stage of the reaction and so tends to prevent agglutination. With very high concentrations of agglutinin it may be supposed that the second effect predominates and a prozone due to pure agglutinin excess is formed.

If incomplete antibody is present as well as agglutinin the sequence of events may be the same as with agglutinin alone, but zoning will occur more readily, since the only effect of the incomplete antibody is to combine with some of the antigen and interfere with the second stage of the reaction.

The crucial question is whether the concentration of agglutinin at the surface of a cell outweighs the blocking effect of the total antibody at the surface of a second cell to which the agglutinin is seeking attachment. Incomplete antibody merely increases this blocking effect, and the blocking effect is the same whether it is caused by agglutinin alone or by incomplete antibody and agglutinin together. In short, zoning can be attributed to the blocking effect of antibody excess.

Furthermore, the cells are not blocked in any absolute sense, but only blocked against a given concentration of agglutinin, since a higher concentration of agglutinin could overcome the blocking effect. This is why cells from the prozone of Experiment 1 will agglutinate in the presence of undiluted agglutinating serum.

Whether or not this explanation of these phenomena is correct does not, of course, affect the validity of the experimental findings, nor detract from the conclusion that agglutination of $\Rightarrow$ cells from the prozone on the addition of cells $\stackrel{\infty}{+}$ with free antigen receptors is no evidence that the $\bar{c}$ original absence of agglutination was due to $\frac{\bar{\sigma}}{\bar{\rho}}$ agglutinin excess. It is, however, a phenomenon $\frac{\omega}{\sigma}$ which is very helpful in attempting to understand $\stackrel{\varnothing}{\circ}$ the mechanism of zoning.

\section{Summary}

Washed cells from a prozone caused by incom- $\omega$ plete anti-D were found to agglutinate on the addition of more D-positive cells, and also on the addition of more anti-D agglutinin. Washed cells from the first negative tube of a titration of a saline agglutinating anti-D serum with $D^{u}$ cells were 0 found to agglutinate in the same circumstances. $\frac{}{J}$ These results show that the phenomenon of agglu- $\vec{c}$ tination of cells from a prozone on the addition of more cells bearing free antigen receptors cannot necessarily be taken to indicate that the prozone was caused by agglutinin excess.

The phenomenon of zoning appears to be due to excessive amounts of antibody at the cell surface interfering with the second stage of the agglutination reaction, in which agglutinin already attached to one cell is seeking attachment to another.

These considerations lead to the supposition $\frac{\gtrsim}{\not}$ that there is no essential difference between $\varrho$ zoning caused by incomplete antibody and that $\overrightarrow{\vec{O}}$ caused by "agglutinin excess." Both are caused $\exists$ by " antibody excess" in the second stage of the reaction.

Our thanks are due to Dr. F. Stratton and Dr. B. Stone for their advice and assistance.

\section{REFERENCES}

Hubinont, P. O. (1951). Brit. med. J., 2, 708.

Loghem, J. J. van (1950). Maandschr. Kindergeneesk., 18, 115. Kresner, M., Coombs, R. R. A., and Roberts, G. Fulton (1950). Lancet, 2, 729.

Taylor, G. L., Race, R. R., Prior, Aileen M., and Ikin, Elizabeth W. (1942). Brit. med. J., 2, 572.

Wiener, A. S. (1944). Proc. Soc. exp. Biol. (N.Y.), 56, 173. 